\title{
Article \\ Virulence, Antimicrobial Resistance and Biofilm Production of Escherichia coli Isolates from Healthy Broiler Chickens in Western Algeria
}

\author{
Qada Benameur ${ }^{1}\left(\mathbb{D}\right.$, Teresa Gervasi ${ }^{2}, * \mathbb{D}$, Filippo Giarratana ${ }^{3}\left(\mathbb{D}\right.$, Maria Vitale $^{4}\left(\mathbb{D}\right.$, Davide Anzà ${ }^{4}$, \\ Erminia La Camera ${ }^{5}$, Antonia Nostro ${ }^{5}$ (D), Nicola Cicero ${ }^{2}$ and Andreana Marino ${ }^{5}$ (D) \\ 1 Nursing Department, Faculty of Nature and Life Sciences, University of Mostaganem, \\ Mostaganem 27000, Algeria; qada.benameur@univ-mosta.dz \\ 2 Department of Biomedical and Dental Sciences and Morphofunctional Imaging, University of Messina, \\ 98100 Messina, Italy; nicola.cicero@unime.it \\ 3 Department of Veterinary Sciences, University of Messina, 98100 Messina, Italy; filippo.giarratana@unime.it \\ 4 Istituto Zooprofilattico Sperimentale della Sicilia "Adelmo Mirri", 90141 Palermo, Italy; \\ maria.vitale@izssicilia.it (M.V.); davide.anza@gmail.com (D.A.) \\ 5 Department of Chemical, Biological, Pharmaceutical and Environmental Sciences, University of Messina, \\ 98100 Messina, Italy; erminia.lacamera@unime.it (E.L.C.); antonia.nostro@unime.it (A.N.); \\ andreana.marino@unime.it (A.M.) \\ * Correspondence: tgervasi@unime.it; Tel.: +39-090-676-2870
}

\section{check for} updates

Citation: Benameur, Q.; Gervasi, T.; Giarratana, F.; Vitale, M.; Anzà, D.; La Camera, E.; Nostro, A.; Cicero, N.; Marino, A. Virulence, Antimicrobial Resistance and Biofilm Production of Escherichia coli Isolates from Healthy Broiler Chickens in Western Algeria. Antibiotics 2021, 10, 1157. https:// doi.org/10.3390/antibiotics10101157

Academic Editors: Manuela Oliveira and Elisabete Silva

Received: 26 August 2021

Accepted: 22 September 2021

Published: 24 September 2021

Publisher's Note: MDPI stays neutral with regard to jurisdictional claims in published maps and institutional affiliations.

Copyright: (c) 2021 by the authors. Licensee MDPI, Basel, Switzerland. This article is an open access article distributed under the terms and conditions of the Creative Commons Attribution (CC BY) license (https:/ / creativecommons.org/licenses/by/ $4.0 /)$.

\begin{abstract}
The aim of this study was to assess the virulence, antimicrobial resistance and biofilm production of Escherichia coli strains isolated from healthy broiler chickens in Western Algeria. E. coli strains ( $\mathrm{n}=18$ ) were identified by matrix-assisted laser desorption-ionization time-of-flight mass spectrometry. Susceptibility to 10 antibiotics was determined by standard methods. Virulence and extended-spectrum $\beta$-lactamase (ESBL) genes were detected by PCR. The biofilm production was evaluated by microplate assay. All the isolates were negative for the major virulence/toxin genes tested ( $r f b E, f l i C, e a e A, s t x 1)$, except one was stx2-positive. However, all were resistant to at least three antibiotics. Ten strains were ESBL-positive. Seven carried the $\beta$-lactamase $b l a_{\mathrm{TEM}}$ gene only and two co-harbored $b l a_{\mathrm{TEM}}$ and $b l a_{\mathrm{CTX}-\mathrm{M}-1}$ genes. One carried the bla $a_{\mathrm{SHV}}$ gene. Among the seven strains harboring $b l a_{\text {TEM }}$ only, six had putative enteroaggregative genes. Two contained irp2, two contained both irp 2 and $a s t A$, one contained $a s t A$ and another contained $a g g R$, ast $A$ and irp 2 genes. All isolates carrying ESBL genes were non-biofilm producers, except one weak producer. The ESBL-negative isolates were moderate biofilm producers and, among them, two harbored ast $A$, two irp2, and one $\operatorname{aggR}$, ast $A$ and irp2 genes. This study highlights the spread of antimicrobial-resistant $E$. coli strains from healthy broiler chickens in Western Algeria.
\end{abstract}

Keywords: virulence genes; antimicrobial resistance; extended-spectrum $\beta$-lactamases; biofilm formation

\section{Introduction}

One of the most important global challenges to public health is represented by foodborne illnesses. Healthy food-producing animals can be vectors for a wide range of commensal and pathogenic bacteria, as well as Escherichia coli. This microorganism can contaminate the food chain at each step, from the slaughterhouses to the food processing phases [1-4]. To date, although several E. coli strains are commensals, which colonize the gastrointestinal tract of humans and warm-blooded animals, and are not often diseasecausing, E. coli represents one of the most frequent causes of several common infections in humans and animals [5]. E. coli clones acquiring specific virulence factors (VFs), including adhesins, toxins, invasins, etc., can cause intestinal and extra-intestinal diseases such as enteric/diarrheal disease, urinary tract infections (UTIs) and sepsis/meningitis in human hosts [6-10]. 
VFs are generally carried on phages, plasmids or pathogenicity islands (PAIs) [11] and, among microbial strains, can be vastly interchanged via horizontal transfer [12]. Given the presence of definite virulence genes, E. coli strains can be classified as pathogens $[13,14]$, in particular as zoonotic intestinal pathogenic E. coli pathotypes (IPEC) or extraintestinal pathogenic E. coli pathotypes (ExPEC) based on the type of VFs present and the host's clinical symptoms [15]. The specific "pathotypes" are grouped into enteropathogenic E. coli (EPEC), enterohaemorrhagic E. coli (EHEC), enterotoxigenic E. coli (ETEC), enteroaggregative E. coli (EAEC), enteroinvasive E. coli (EIEC) and diffusely adherent E. coli (DAEC), and can cause intestinal diseases $[8,16]$.

Moreover, the emergence of antibiotic resistance in food pathogens represents further complications.

The wide use of antibiotics, in both animals and humans, is responsible for an increased antibiotic resistance not only in pathogenic bacteria, but also in the endogenous microflora. Resistant animal bacteria can be transmitted to humans through several routes, such as direct contact with the animal or its manure, and through contact with or the consumption of uncooked meat [17-21]. Given the development of combined resistance to multiple antibiotics such as the $\beta$-lactam group, including cephalosporins and carbapenems, over the last few years, the chemotherapeutic choices for enterobacteria are becoming strictly limited [22]. Resistance to cephalosporin is the result of the production of one or more types of $\beta$-lactamases, the so called extended spectrum- $\beta$-lactamases (ESBLs) [23]. ESBLs are categorized into several classes, among which the most important include Temoniera (TEM), sulfhydryl variable (SHV) and cefotaximase (CTX-M) types [24,25]. Thus, nowadays ESBL-producing Gram-negative bacteria represent a growing concern and an important challenge for chemotherapy [26]. In addition, another issue is represented by the fact that, in food factory environments, some biofilm-forming bacteria are human pathogens. Biofilms are ecosystems made up of one or more bacterial species submerged in an extracellular matrix, whose composition varies according to the colonizing species and the food manufacturing environment [27-29].

The zoonotic potential of $E$. coli from chicken food products is important for public health purposes [30,31]. Meat harbors different bacteria as inherent contamination and is further contaminated during handling, improper dressing, cleaning, unsanitary conditions and unhygienic practices during its commercialization [32]. Considering the factors described, the objective of this preliminary study was to examine virulence and antimicrobial resistance (AMR) gene profiles, and the ability of biofilm formation of E. coli strains isolated from healthy broiler chickens in Western Algeria. The Algerian poultry industry, consisting of 20,000 farmers, every year yields an average of 340,000 tons of white meat and over 4.8 billion eggs. The present Algerian poultry industry structure is the result of government development policies, which were initiated in the 1980s [33].

\section{Results}

A total of 18 presumptive E. coli strains were isolated from 32 fecal samples, collected from different broiler chicken farms situated in five geographic areas of Western Algeria: Mostaganem ( $n=8,25.0 \%)$, Oran $(n=6,18.75 \%)$, Mascara $(n=6,18.75 \%)$, Relizane $(n=6$, $18.75 \%$ ) and Tiaret $(n=6,18.75 \%)$. MALDI-TOF-MS analysis confirmed the identification of all the 18 presumptive E. coli strains (Table 1). All the isolates were negative for the major virulence/toxin genes tested, including shiga-like toxin 1 (stx1), O157:H7 serotype ( $r f b E$ ), flagellar gene $(f l i C)$ and attaching and effacing gene (eaeA), except for one E. coli strain positive for the shiga-like toxin 2 (stx2) gene (Table 1), coming from $1 / 7$ broiler houses located in the Mostaganem area. 
Table 1. Characteristics of E. coli isolates.

\begin{tabular}{|c|c|c|c|c|c|}
\hline Strains & Algerian Area & Virulence Gene ${ }^{1}$ & $\begin{array}{l}\text { MALDI-TOF } \\
\text { Mean Value }\end{array}$ & bla Gene ${ }^{2}$ & $\mathrm{AMR}^{3}$ \\
\hline $\mathrm{S} 13 / 15$ & Oran & ast $A$ & $90.0 \%$ & None & $\begin{array}{c}\text { NA, CIP, AML, SXT, } \\
\text { TE, N }\end{array}$ \\
\hline $\mathrm{S} 14 / 15$ & Oran & $\operatorname{irp} 2$ & $87.4 \%$ & CTX-M-1, TEM & $\begin{array}{c}\text { NA, CIP, AUG, SXT, TE, } \\
\text { N, CTX }\end{array}$ \\
\hline $\mathrm{S} 2 / 15$ & Oran & $\operatorname{irp} 2$ & $85.1 \%$ & TEM & $\begin{array}{l}\text { NA, CIP, AML, AUG, } \\
\text { SXT, TE, N, CTX }\end{array}$ \\
\hline $\mathrm{S} 4 / 15$ & Mostaganem & stx 2 & $87.5 \%$ & None & $\begin{array}{c}\text { NA, AML, AUG, SXT, } \\
\text { TE, N }\end{array}$ \\
\hline $\mathrm{S} 19 / 15$ & Mostaganem & None & $93.0 \%$ & CTX-M-1, TEM & $\begin{array}{l}\text { NA, CIP, AML, AUG, } \\
\text { SXT, TE, C, N, CTX }\end{array}$ \\
\hline S12/15 & Mostaganem & $\operatorname{agg} R$, ast $A$, irp 2 & $85.8 \%$ & TEM & $\begin{array}{l}\text { NA, CIP, AML, AUG, } \\
\text { SXT, TE, N, CTX }\end{array}$ \\
\hline $\mathrm{S} 25 \mathrm{a} / 16$ & Mostaganem & ast $A$ & $88.7 \%$ & None & NA, CIP, AUG, TE, N \\
\hline S1/16 & Mostaganem & ast $A$, irp2 & $97.7 \%$ & TEM & $\begin{array}{l}\text { NA, CIP, AML, AUG, } \\
\text { SXT, TE, N, CTX }\end{array}$ \\
\hline $\mathrm{S} 22 / 15$ & Mostaganem & ast $A$, irp2 & $89.4 \%$ & TEM & $\begin{array}{l}\text { NA, CIP, AML, AUG, } \\
\text { SXT, TE, N, CTX }\end{array}$ \\
\hline S16/15 & Mostaganem & $\operatorname{irp} 2$ & $92.6 \%$ & None & $\begin{array}{c}\text { NA, CIP, AML, AUG, } \\
\text { SXT, TE, N }\end{array}$ \\
\hline S34/16 & Relizane & $\operatorname{irp} 2$ & $93.3 \%$ & None & NA, CIP, N \\
\hline $\mathrm{S} 31 / 16$ & Relizane & None & $91.2 \%$ & None & NA, CIP, TE, N \\
\hline S33/16 & Relizane & $a g g R$, ast $A$, irp 2 & $90.3 \%$ & None & $\begin{array}{l}\text { NA, CIP, AML, AUG, } \\
\text { SXT, TE, C, N }\end{array}$ \\
\hline S47/16 & Tiaret & $\operatorname{irp} 2$ & $95.2 \%$ & TEM & $\begin{array}{l}\text { NA, CIP, AML, AUG, } \\
\text { SXT, TE, N, CTX }\end{array}$ \\
\hline S6/15 & Tiaret & None & $96.5 \%$ & None & $\begin{array}{c}\text { NA, CIP, AML, AUG, } \\
\text { TE, N }\end{array}$ \\
\hline $\mathrm{S} 48 \mathrm{a} / 16$ & Tiaret & ast $A$ & $93.4 \%$ & TEM & $\begin{array}{l}\text { NA, CIP, AML, AUG, } \\
\text { SXT, TE, C, N, CTX }\end{array}$ \\
\hline $\mathrm{S} 19 \mathrm{a} / 16$ & Mascara & None & $92.7 \%$ & TEM & $\begin{array}{l}\text { NA, CIP, AML, AUG, } \\
\text { SXT, TE, N, CTX }\end{array}$ \\
\hline S61a/16 & Mascara & None & $95.0 \%$ & SHV & NA, AUG, SXT, TE, N \\
\hline $\begin{array}{c}\text { E. coli } \\
\text { ATCC } 259222\end{array}$ & & & $99.9 \%$ & & AML, AUG \\
\hline
\end{tabular}

${ }^{1}$ ast $A$, heat-stable enterotoxin-1; irp2, iron regulatory protein 2; stx2, shiga-like toxin 2; aggR, transcription factor; ${ }^{2}$ TEM, temoniera; CTX-M-1, cefotaximases; SHV, sulfhydryl variable; ${ }^{3}$ AMR, antimicrobial resistance; NA, nalidixic acid; N, neomycin; TE, tetracycline; CIP, ciprofloxacin; AUG, amoxicillin-clavulanic acid; STX, trimethoprim-sulfamethoxazole; AML, amoxicillin; CTX, cefotaxime; C, chloramphenicol.

However, in contrast to the low percentage of virulence genes detected, all strains were shown to be resistant to at least three antibiotics most frequently used in poultry (Table 1). They were resistant to nalidixic acid (NA) (100\%), neomycin (N) (100\%), tetracycline (TE) (94\%), ciprofloxacin (CIP) (89\%), amoxicillin-clavulanic acid (AUG) (83\%), trimethoprimsulfamethoxazole (SXT) $(78 \%)$, amoxicillin (AML) $(72 \%)$, cefotaxime (CTX) (50\%) and chloramphenicol (C) (17\%). Among the strains, 10 were phenotypically confirmed to be ESBL-positive isolates. Genotypic analyses revealed that nine strains (CTX-resistant $50 \%)$ carried the $b l a_{\mathrm{TEM}}$ gene and one harbored the $b l a_{\mathrm{SHV}}$ gene $(5.55 \%)$. Among the $b l a_{\mathrm{TEM}}$-producing E. coli isolates, two co-harbored the bla $a_{\mathrm{CTX}-\mathrm{M}-1}$ gene (11\%) (Table 2). The distribution of the percentages of ESBL isolates and the geographical area visited was $67 \%$ in Oran, 57\% in Mostaganem, 67\% in Tiaret, 50\% in Mascara and none in Relizane.

Furthermore, an association between biofilm production and the presence of enteroaggregative genes was evaluated. 
Table 2. Enteroaggregative and ESBL genes and biofilm production of E. coli isolates.

\begin{tabular}{|c|c|c|c|c|c|c|c|c|}
\hline Strains & $\operatorname{aggR}$ & $\operatorname{irp} 2$ & ast $A$ & TEM & CTX-M-1 & SHV & SBF & Biofilm Grade \\
\hline $\mathrm{S} 13 / 15$ & & & + & & & & 0.81 & $\mathrm{M}$ \\
\hline $\mathrm{S} 14 / 15$ & & + & & + & + & & 0.16 & $\mathrm{~N}$ \\
\hline $\mathrm{S} 2 / 15$ & & + & & + & & & 0.26 & $\mathrm{~N}$ \\
\hline $\mathrm{S} 4 / 15$ stx 2 & & & & & & & 0.76 & M \\
\hline S19/15 & & & & + & + & & 0.20 & $\mathrm{~N}$ \\
\hline $\mathrm{S} 12 / 15$ & + & + & + & + & & & 0.18 & $\mathrm{~N}$ \\
\hline $\mathrm{S} 25 \mathrm{a} / 16$ & & & + & & & & 0.62 & W \\
\hline $\mathrm{S} 1 / 16$ & & + & + & + & & & 0.19 & $\mathrm{~N}$ \\
\hline $\mathrm{S} 22 / 15$ & & + & + & + & & & 0.29 & $\mathrm{~N}$ \\
\hline S16/15 & & + & & & & & 0.45 & W \\
\hline $\mathrm{S} 34 / 16$ & & + & & & & & 0.52 & W \\
\hline $\mathrm{S} 31 / 16$ & & & & & & & 0.84 & M \\
\hline $\mathrm{S} 33 / 16$ & + & + & + & & & & 0.65 & W \\
\hline$S 47 / 16$ & & + & & + & & & 0.39 & W \\
\hline $\mathrm{S} 6 / 15$ & & & & & & & 0.59 & W \\
\hline $\mathrm{S} 48 \mathrm{a} / 16$ & & & + & + & & & 0.22 & $\mathrm{~N}$ \\
\hline $\mathrm{S} 19 \mathrm{a} / 16$ & & & & + & & & 0.24 & $\mathrm{~N}$ \\
\hline S61a/16 & & & & & & + & 0.27 & $\mathrm{~N}$ \\
\hline \multicolumn{9}{|l|}{ E. coli } \\
\hline ATCC & & & & & & & 0.76 & M \\
\hline 25922 & & & & & & & & \\
\hline
\end{tabular}

$\operatorname{aggR}$, transcription factor; irp2, iron regulatory protein 2; ast A, heat-stable enterotoxin-1; TEM, temoniera; CTX-M-1, cefotaximases; SHV, sulfhydryl variable; $S B F$, specific biofilm formation; + gene presence; $M$, moderate (SBF $\geq 0.70-1.09)$; $N$, negative $(S B F<0.35)$; $W$, weak $(\mathrm{SBF} \geq 0.35-0.69)$.

Enteroaggregative genes were detected in the ESBL-producing strains (Table 1). Among the seven strains harboring only $b a_{\mathrm{TEM}-1}$, two strains contained iron regulatory protein 2 (irp2) (28.5\%), two both irp2 and the heat-stable enterotoxin-1 (ast A) (28.5\%), one ast $A(14 \%)$ and another the transcription factor $(a g g R)$, ast $A$ and irp2 $(14 \%)$ genes. Two strains contained $b l a_{\mathrm{TEM}} / b l a_{\mathrm{CTXM}-1}$, and one had the $\operatorname{irp} 2(50 \%)$ gene. Among all ESBL-producing strains, only one isolate, harboring bla $a_{\mathrm{TEM}}$ and irp2 genes, was a weak biofilm producer (14\%) (Table 2). The remaining strains (86\%) were regarded as non-biofilm producers (specific biofilm formation (SBF): 0.16-0.29).

Among the eight non-ESBL-producing strains, five (62.5\%) harbored putative enteroaggregative genes: ast $A(\mathrm{n}=2,25 \%)$, irp2 $(\mathrm{n}=2,25 \%)$ and ast $A$-irp2-aggR $(\mathrm{n}=1$, $12.5 \%)$. Moreover, one isolate (12.5\%) expressed the st $x 2$ gene (Table 1$)$. The non-ESBLproducing isolates were more likely to produce biofilm than ESBL-producing strains $(p \geq 0.001 ; r=0.85)$. Among the non-ESBL-producing isolates, three strains were classified as moderate biofilm producers (Table 2). One harbored ast $A(12.5 \%)$, another stx 2 $(12.5 \%)$ and yet another contained no virulence gene (12.5\%), with SBF: 0.81, SBF: 0.76 and SBF: 0.84 , respectively. The remaining strains $(62.5 \%)$ were regarded as weak biofilm producers (SBF: 0.39-0.65). E. coli ATCC 25922 was a moderate biofilm producer (SBF: 0.81).

\section{Discussion}

The majority of E. coli strains are commensals inhabiting the intestinal tract of humans and warm-blooded animals and rarely cause diseases, unless they acquire VFs carried by mobile genetic elements such as bacteriophages, pathogenicity islands and plasmids [34]. Additionally, E. coli can form a reservoir of AMR genes that may be transferred among different bacterial species, including pathogenic bacteria for both humans and animals.

In this study, the E. coli strains, isolated from fecal samples of apparently healthy chickens, showed a low percentage of virulence genes, which are characteristic of shiga toxin-producing E. coli (STEC O157:H7) ( $r f b E$, fliC, eaeA and stx1). Indeed, except for one E. coli strain, which was positive for the $s t x 2$ gene detected at one Mostaganem farm, all the isolates were negative for the major genes encoding VFs. This finding is in accordance with previous Algerian studies describing a low prevalence of stx genes in E. coli isolates 
from poultry origin, i.e., a recent Algerian study showed the presence of stx 2 in only one E. coli isolate from broiler chickens, which had just died [35]. Another study conducted in the north of Algeria revealed the total absence of the st $x 2$ gene and the presence of the stx1 gene in only two E. coli strains isolated from diarrheic hens and chickens [36]. Our results are also in agreement with several previous studies conducted in other countries, which concluded that the prevalence of STEC O157:H7 in broiler chickens is relatively low compared with other animal species [37-40].

However, in contrast to the low percentage of STEC virulence genes detected, all isolated strains were shown to be resistant to at least three antibiotics most frequently administered to poultry. Antimicrobial agents are being used in many countries in veterinary practice for the treatment of disease, disease prevention and growth promotion [41]. However, the indiscriminate use of antimicrobials can result in bacterial selection pressure of the intestinal microbiota of animals $[19,42,43]$.

The high levels of resistance of the isolated strains against more than three antibiotics were not surprising given the uncontrolled use of these antibiotics in poultry in Algeria and their use without prior antimicrobial susceptibility tests. It must also be noted that the lack of legislative restrictions on antibiotic use in the poultry industry could also lead to a build-up of antibiotic resistance, i.e., they are still used in poultry feeds at sub-therapeutic dosages for growth promotion purposes (to reduce bird mortality and improve production performance). In contrast, this practice is banned in many countries, including those of the European Union, to avoid AMR diffusion in pathogenic bacteria in food-producing animals [44]. The high level of resistance recorded in this study for CTX $(50 \%)$ is troubling as third-generation cephalosporins (ceftiofur) are not used in Algerian poultry production. These results are in agreement with those reported in other studies [45,46], which highlighted the emergence and persistence of ESBL-producing E. coli in the poultry production pyramid in many countries despite the absence of third-generation cephalosporin usage. This might be linked to the abuse and misuse of other antimicrobials (i.e., aminoglycosides, $\beta$-lactams, quinolones, macrolides, nitrofurans, phenicols, polypeptides, sulphonamides and tetracyclines) in broiler breeding or to the selection of ESBL-producing E. coli in broiler breeders and their vertical transmission in the poultry production pyramid [47-50]. The high levels of ESBL-producing E. coli isolates in Mostaganem, Oran, Mascara, Relizane and Tiaret could be explained by their horizontal transmission in broiler farms and hatcheries, as previously suggested [51], during broiler chicken transfer and likewise through national trade to several regions of the country. In addition, encoding cephalosporin resistance genes are generally placed on self-transmissible plasmids [52], which can be promiscuous and are capable of circulating among a wide variety of hosts. Despite the fact that thirdgeneration cephalosporins are not used in Algerian poultry production, several studies highlighted their colonization in broiler chickens in the last few years [53-55]. The genetic background for cephalosporin resistance was diverse in those studies. Benameur et al. [54] reported the presence of the $b l a_{\mathrm{CTX}-\mathrm{M}-1}$ gene and Meguenni et al. [55] showed the presence of $b l a_{\mathrm{CTX}-\mathrm{M}-1}$ and $b l a_{\mathrm{CTX}-\mathrm{M}-15}$. Furthermore, Belmahdi et al. [53] detected the presence of $b l a_{\mathrm{CTX}-\mathrm{M}-1}, b l a_{\mathrm{SHV}-12}$ and $b l a_{\mathrm{TEM}-1}$.

However, in our study, the most prevalent group was bla $a_{\mathrm{TEM}}$ followed by bla $a_{\mathrm{TEM}}$ and $b l a_{\mathrm{CTX}-\mathrm{M}-1}$ gene combinations and $b l a_{\mathrm{SHV}}$, like the findings in a study in Turkey that demonstrated $b l a_{\mathrm{TEM}}$ as the most frequent gene, followed by $b a_{\mathrm{CTX}-\mathrm{M}}$ and $b l a_{\mathrm{SHV}}$ [56].

In many other studies, multiple occurrences of the genes were also common [57], given that these genes frequently exist in large plasmids [58]. SHV and TEM were the main types of ESBL until 2000, while, in recent decades, CTX-M enzymes took their place [59].

All genes encoding resistance to macrolides, quinolones, tetracyclines, aminoglycosides, trimethoprim, chloramphenicol and sulfonamides have been associated with plasmids containing the $b l a_{\mathrm{CTX}-\mathrm{M}}$ type [60]. The association of antibiotics, and the coexistence of $b l a_{\text {CTX-M }}$ genes with $b l a_{\text {TEM }}$ or other resistance determinants, could contribute to the spread of CTX-M enzymes. Nowadays, enzymes of the CTX-M-1 group are frequently identified in North Africa [61]. 
This issue is further worsened by the formation of biofilm, which promotes an additional bacterial tolerance or resistance to antimicrobial agents $[29,62]$ and represents an advantage in the survival against host defense factors, antibiotics, physical and chemical stress as well as disinfectants $[63,64]$.

In this study, the ability of biofilm formation was found to be significantly higher in negative ESBL strains of E. coli than in strains carrying the bla $a_{\mathrm{TEM}}$ gene. However, despite the small number of strains used in this study, the results align with those of other authors who demonstrate that the expression of the bla $a_{\text {TEM }}$ gene can negatively impact biofilm formation in E. coli [65].

The production of biofilm is also regulated by putative enteroaggregative genes such as the transcription activator known as "aggR", the master regulator of EAEC virulence, which controls the expression of adherence factors, and several other genes including yersiniabactin operon (irp2) and EAST1 toxin (astA) [61].

However, according to other authors, no correlation was reported between $a g g R$ alone or in association with irp 2 and ast $A$ and biofilm formation in producing isolates, indicating that there are additional factors involved in biofilm production in EAEC $[9,66,67]$.

\section{Materials and Methods}

\subsection{Study Area and Sampling}

A total of 16 broiler farms were randomly selected to carry out this study. All the farms were located within five geographic areas of Western Algeria, namely Mostaganem, Oran, Mascara, Relizane and Tiaret, representing the major broiler poultry producing sites in Algeria. Each broiler farm comprised several houses. Two poultry houses were sampled from each farm and one sample per house was collected. The poultry houses were chosen by considering their capacities (at least 3000 birds per house). All the farms included in this study were under control by official veterinary services. Broilers were commonly kept for a short period, which is generally less than two months. All broiler farms were visited once and sampling was carried out a few days before submission of the birds to slaughter. Fresh (still soft and warm) poultry feces was sampled from the poultry houses and transported to the laboratory for isolation of E. coli. All sampled broiler flocks were apparently healthy on the day of sampling.

\subsection{Escherichia coli Isolation}

Between March and September 2020, a total of 32 fecal samples, collected from different broiler chicken farms situated in five geographic areas of Western Algeria (Mostaganem, Oran, Mascara, Relizane, Tiaret), were analyzed in this study. To isolate E. coli, one gram of fecal specimens was mixed with $9 \mathrm{~mL}$ of buffered peptone water and incubated for $18 \mathrm{~h}$ at $37^{\circ} \mathrm{C}$. A drop was then streaked on MacConkey agar (MAC, Oxoid, Hampshire, UK) plates and incubated for $18 \mathrm{~h}$ at $37^{\circ} \mathrm{C}$. E. coli ATCC 25922 and ATCC 10536 (American Type Culture Collection, Rockville, MD, USA) were used as reference strains. Single colonies were stored in glycerol at $-80^{\circ} \mathrm{C}$ until further testing.

\subsection{Identification of Colonies by MALDI-TOF-MS}

The presumptive E. coli colonies were identified by matrix-assisted laser desorptionionization time-of-flight mass spectrometry (MALDI-TOF-MS). Briefly, strains were cultured on tryptic soy agar (TSA; Oxoid, Hampshire, UK) supplemented with $5 \%$ of sheep blood and incubated at $37^{\circ} \mathrm{C}$ for $24 \mathrm{~h}$.

A single bacterial colony was deposited on FlexiMass MALDI target plates, with 48-well sample spots (bioMérieux, Firenze, Italy), followed by the addition of $1 \mu \mathrm{L}$ of matrix of alpha-cyano-4-hydroxycinnamic acid matrix in 50\% acetonitrile and $2.5 \%$ trifluoroacetic acid (Vitek MS-CHCA, bioMérieux, Firenze, Italy).

E. coli ATCC 8739, used as a calibrator and internal ID control, grown on TSA, which was supplemented with $5 \%$ of sheep blood (according to the constructor procedure) and incubated at $37^{\circ} \mathrm{C}$ for $24 \mathrm{~h}$, was inoculated on the calibration spots as well as the test strains. 
The prepared plate, after the complete crystallization of the microbial matrix complex, was inserted in a Vitek MS Axima Assurance linear mass spectrometer (bioMérieux, Firenze, Italy) set with a laser frequency of $50 \mathrm{~Hz}$, an acceleration voltage of $20 \mathrm{kV}$, an extraction delay time of $200 \mathrm{~ns}$ and mass spectra from 2000 to 20,000 Da. Every single strain was analyzed three times in three separate runs at different times.

The obtained mass spectra for each microorganism were analyzed by SARAMIS software (Spectral ARchive And Microbial Identification System-Database version 4.10-Software year 2010, bioMérieux, Firenze, Italy) by comparing them with the database bacteria reference spectra. The result of this comparison, calculated by the software algorithm, is a percentage probability (confidence level) that represents the similarity (presence or absence of specific peaks) among the obtained spectra and the reference spectra.

A perfect match reported as "excellent ID" corresponded to a percentage probability of identification (confidence level) of $99.9 \%$, a "good ID" from $>60 \%$ to $99.8 \%$, while for $<60 \%$ "no identification" (no ID) was given.

\subsection{Genes Encoding VF Detection by Polymerase Chain Reaction}

All E. coli isolates were tested for the genes encoding VFs characteristic of pathogenic E. coli O157:H7: stx1, st x2, rfbE, fliC and eaeA, using specific primers [68]. Each polymerase chain reaction (PCR) reaction was performed in a $50 \mu \mathrm{L}$ amplification mixture consisting of $10 \mu \mathrm{L} 5 \times$ PCR buffer $\left(1.5 \mathrm{mM} \mathrm{MgCl}_{2}\right), 5.0 \mu \mathrm{L}$ dNTPs $(2.5 \mathrm{mM}), 1 \mu \mathrm{L}$ of each primer $(10 \mu \mathrm{M})$, $0.25 \mu \mathrm{L}$ of GoTaq DNA polymerase ( 5 unit $/ \mu \mathrm{L}$ ) and $10 \mu \mathrm{L}$ of template. E. coli ATCC 43894 was used as a reference strain (E. coli O157:H7). The sequence of the used primers and the conditions of PCR were performed according to Tabashsum et al. [68]. Amplification products were separated by electrophoresis on $1.5 \%$ agarose gel, on $1 \times$ Tris-Acetate-EDTA (242 g/L trizma base; $57.1 \mathrm{~mL} / \mathrm{L}$ glacial acetic acid; $100 \mathrm{~mL} / \mathrm{L}$ EDTA $0.5 \mathrm{M} \mathrm{pH} \mathrm{8.0)} \mathrm{at} 100 \mathrm{~V}$ for $1 \mathrm{~h}$ and then visualized by GelRed staining, illuminated by UV transilluminator and visualized by a gel reader (Bio Rad Gel DOC XR+, Hercules, CA, USA). A 100 bp DNA ladder was used as a marker for PCR assay. The expected sizes of products for $e a e A, r f b$ O157 and fliC $\mathrm{H} 7$ gene amplification were 150, 259 and $625 \mathrm{bp}$, and for st 1 and stx 2 genes were 348 and $584 \mathrm{bp}$, respectively [68].

\subsection{Antimicrobial Susceptibility Testing}

Antimicrobial susceptibility of the isolates was tested using the Kirby Bauer method according to the Clinical and Laboratory Standards Institute (CLSI) guidelines [69]. The following antibiotics were tested: NA, $30 \mu \mathrm{g}$; CIP, $5 \mu \mathrm{g}$; AML, $25 \mu \mathrm{g}$; AUG, 20/10 $\mu$; CTX, $30 \mu \mathrm{g}$; TE, $30 \mu \mathrm{g}$; SXT, 1,25/23,75 $\mu \mathrm{g}$; N, $30 \mu \mathrm{g}$; C, $30 \mu \mathrm{g} ; \mathrm{CT}, 50 \mu \mathrm{g}$ (Oxoid, Hampshire, UK). Briefly, the isolates were grown on TSA for $24 \mathrm{~h}$ at $37^{\circ} \mathrm{C}$. Subsequently, each bacterial suspension was adjusted to McFarland 0.5 in normal saline and uniformly spread onto Mueller-Hinton agar (MHA; Oxoid, Hampshire, UK). Paper disks impregnated with antibiotics were placed on the surface of agar plates and incubated for $24 \mathrm{~h}$ at $37{ }^{\circ} \mathrm{C}$ aerobically. Then, the diameters of the inhibition zones were measured by using a Vernier caliper and the values were interpreted according to the CLSI guidelines [69]. E. coli ATCC 25922 and ATCC 10536 (American Type Culture Collection, Rockville, MD, USA) were used as quality control strains.

\subsection{Phenotypic Confirmation of ESBL Production}

Phenotypic confirmation of ESBL production was performed by double-disk synergy test according to the CLSI guidelines [69], by positioning an AUG disk at a distance of $30 \mathrm{~mm}$ to third-generation cephalosporin disk (CTX) on MHA. The test was considered as positive when a synergy (champagne cork aspect) between AUG and CTX disks was observed in combination with resistance or reduced susceptibility to third-generation cephalosporin. Isolates showing decreased susceptibility to third-generation cephalosporin without clear synergy were subjected to a Combination Disk Test, by applying disks 
containing third-generation cephalosporin alone and in combination with clavulanic acid, following CLSI guidelines [69].

\subsection{ESBL Gene Identification by PCR}

DNA of the isolated E. coli strains was prepared by boiling methods. Briefly, for each strain, 2 or 3 colonies were dissociated in $1 \mathrm{~mL}$ of distilled sterile water and centrifuged for $5 \mathrm{~min}$ at 13,000 $\mathrm{rpm}$. The supernatant was eliminated, and the pellet was suspended in $200 \mu \mathrm{L}$ of distilled sterile water and heated at $100{ }^{\circ} \mathrm{C}$ for $10 \mathrm{~min}$, cooled on ice for $5 \mathrm{~min}$, and the DNA was removed from the supernatant after $5 \mathrm{~min}$ of centrifugation $(13,000 \mathrm{rpm})$ to pellet the cellular debris and stored at $-20^{\circ} \mathrm{C}$ until use. Genetic characterization of ESBLs was performed on phenotypically confirmed E. coli isolates by PCR. The sequence of primers and the conditions of PCR for the detection of $b a_{\mathrm{ESBL}}$ genes were performed as described previously for $b l a_{\mathrm{CTX}-\mathrm{M}}$ genotype groups $1,2,8$ and 9, bla $a_{\mathrm{SHV}}$ [70] and bla $a_{\mathrm{TEM}}$ [71]. Amplification products were separated by gel electrophoresis using a $2 \%$ agarose gel.

\subsection{Putative Enteroaggregative Gene Detection by PCR}

The isolates were also investigated for the detection of various enteroaggregative putative genes: aggr, ast $A$ and irp2. The sequence of the used primers and the conditions of PCR were performed according to Mohamed et al. [9].

\subsection{Biofilm Formation Assay}

All E. coli isolates were evaluated for their ability to form biofilm by staining assay, as described by Cramton et al. [72] with some minor modifications. Briefly, overnight cultures in tryptic soy broth (TSB) were adjusted in culture medium to $5 \times 10^{5} \mathrm{CFU} / \mathrm{mL}$ and then $200 \mu \mathrm{L}$ was dispensed into all the wells of the microtiter plate. The biofilm biomass formed in each well, after incubation for $24 \mathrm{~h}$ at $37^{\circ} \mathrm{C}$, was washed twice with phosphate-buffered saline (PBS), dried at room temperature, stained with aqueous $0.1 \%$ safranin solution $(200 \mu \mathrm{L})$ for $1 \mathrm{~min}$ and then washed with water. The stained biofilms were dissolved in $30 \%(v / v)$ acetic acid and measured at OD $492 \mathrm{~nm}$ using a microplate reader. The following formula was applied to classify the biofilm formation: $\mathrm{SBF}=(\mathrm{AB}-\mathrm{CW}) / \mathrm{G}$, where $\mathrm{AB}$ is the stained attached bacteria (OD $492 \mathrm{~nm}$ ), CW is the stained control wells containing bacteria-free medium only (OD $492 \mathrm{~nm}$ ) and G is the cell growth in suspended culture (OD $540 \mathrm{~nm}$ ) [73]. E. coli ATCC 25922 served as a positive control. TSB without bacteria was included as medium control.

The degree of biofilm formation of the isolates was classified into 4 categories: negative (SBF $<0.35$ ), weak (SBF $\geq 0.35-0.69$ ), moderate (SBF $\geq 0.70-1.09)$ and strong (SBF $\geq 1.10$ ) [74].

\subsection{Statistical Analysis}

All experiments were performed in triplicate. Statistical data analysis was carried out using MATLAB_R2020a (MatWorks, Inc. Natick, MA, USA). A two-tailed Student's $t$-test was applied to evaluate the mean \pm standard deviation and the significant differences in the grade of biofilm formation among different strains. For each comparison between virulence or resistance genes and biofilm formation, a correlation coefficient $(r)$ was determined via Pearson's analysis. $p$-values of $\leq 0.05$ were considered significant in all experiments.

\section{Conclusions}

In conclusion, our results reported a low frequency of virulence-associated genes of STEC O157:H7 in E. coli strains isolated from different poultry farms in Western Algeria. However, all isolates were shown to be resistant to at least three antibiotics most frequently used in poultry, and among these more than half were ESBL-positive E. coli despite no use of third-generation cephalosporins in Algerian poultry production. The ability of biofilm formation, which is considered a further virulent factor in pathogenic bacteria, was instead found to be higher among non-ESBL-producing strains of E. coli. Given that E. coli in chickens represents one of the major opportunistic pathogens and that it can be easily 
transferred from animals to humans, ESBL-producing E. coli represents an important risk factor for the poultry industry and human health. This study emphasizes the importance of monitoring the spread of the E. coli isolates that harbor virulence and antibiotic resistance genes in poultry farms, including the ones with healthy chickens, in order to prevent and control the spread of resistant bacteria and their virulence genes.

In Algeria, antimicrobials are not only used for therapeutic reasons but also for growth promotion and disease prevention. Consequently, the Algerian authorities should enforce AMR rules in order to guarantee a wise use of antimicrobials that will limit the risk of transmission along the food chain.

Author Contributions: Conceptualization, A.M., Q.B. and T.G.; Methodology, Q.B., T.G., F.G., D.A. and E.L.C.; Investigation, F.G., M.V., A.N., E.L.C. and N.C.; Writing-original draft preparation, A.M., Q.B. and T.G.; Data curation, A.N., N.C. and M.V.; Writing-review and editing, A.M. and T.G.; Funding acquisition, A.M. All authors have read and agreed to the published version of the manuscript.

Funding: This research received no external funding.

Institutional Review Board Statement: Not applicable.

Conflicts of Interest: The authors declare no conflict of interest.

\section{References}

1. Das, Q.; Islam, R.; Marcone, M.; Warriner, K.; Diarra, M. Potential of berry extracts to control foodborne pathogens. Food Control 2017, 73, 650-662. [CrossRef]

2. Gordon, D.M.; Cowling, A. The distribution and genetic structure of Escherichia coli in Australian vertebrates: Host and geographic effects. Microbiology 2003, 149, 3575-3586. [CrossRef]

3. Liu, C.M.; Stegger, M.; Aziz, M.; Johnson, T.J.; Waits, K.; Nordstrom, L.; Gauld, L.; Weaver, B.; Rolland, D.; Statham, S.; et al. Escherichia coli ST131-H22 as a Foodborne Uropathogen. mBio 2018, 9. [CrossRef] [PubMed]

4. Osman, K.M.; Kappell, A.D.; Elhadidy, M.; ElMougy, F.; El-Ghany, W.A.A.; Orabi, A.; Mubarak, A.S.; Dawoud, T.M.; Hemeg, H.A.; Moussa, I.M.I.; et al. Poultry hatcheries as potential reservoirs for antimicrobial-resistant Escherichia coli: A risk to public health and food safety. Sci. Rep. 2018, 8, 5859. [CrossRef] [PubMed]

5. Ramos, S.; Silva, V.; Dapkevicius, M.L.E.; Canica, M.; Tejedor-Junco, M.T.; Igrejas, G.; Poeta, P. Escherichia coli as Commensal and Pathogenic Bacteria Among Food-Producing Animals: Health Implications of Extended Spectrum beta-lactamase (ESBL) Production. Animals 2020, 10, 2239. [CrossRef] [PubMed]

6. Donnenberg, M.S. Escherichia coli Virulence Mechanisms of a Versatile Pathogen; Academic press: Baltimore, MD, USA; Elsevier Science: Amsterdam, The Netherlands, 2002.

7. Johnson, J.R.; Porter, S.B.; Zhanel, G.; Kuskowski, M.A.; Denamur, E. Virulence of Escherichia coli clinical isolates in a murine sepsis model in relation to sequence type ST131 status, fluoroquinolone resistance, and virulence genotype. Infect. Immun. 2012, 80, 1554-1562. [CrossRef]

8. Kaper, J.B.; Nataro, J.P.; Mobley, H.L. Pathogenic Escherichia coli. Nat. Rev. Microbiol. 2004, 2, 123-140. [CrossRef]

9. Mohamed, J.A.; Huang, D.B.; Jiang, Z.D.; DuPont, H.L.; Nataro, J.P.; Belkind-Gerson, J.; Okhuysen, P.C. Association of putative enteroaggregative Escherichia coli virulence genes and biofilm production in isolates from travelers to developing countries. J. Clin. Microbiol. 2007, 45, 121-126. [CrossRef]

10. Patel, J.; Yin, H.B.; Bauchan, G.; Mowery, J. Inhibition of Escherichia coli O157:H7 and Salmonella enterica virulence factors by benzyl isothiocyanate. Food Microbiol. 2020, 86, 103303. [CrossRef]

11. Hacker, J.; Kaper, J.B. Pathogenicity islands and the evolution of microbes. Annu. Rev. Microbiol. 2000, 54, 641-679. [CrossRef] [PubMed]

12. Huddleston, J.R. Horizontal gene transfer in the human gastrointestinal tract: Potential spread of antibiotic resistance genes. Infect. Drug Resist. 2014, 7, 167-176. [CrossRef]

13. Arabi, S.; Jafarpour, M.; Mirinargesi, M.; Asl, S.B.; Naghshbandi, R.; Shabanpour, M. Molecular characterization of avian pathogenic Escherichia coli in broilers bred in northern Iran. Glob. Vet. 2013, 10, 382-386.

14. Dissanayake, D.R.; Octavia, S.; Lan, R. Population structure and virulence content of avian pathogenic Escherichia coli isolated from outbreaks in Sri Lanka. Vet. Microbiol. 2014, 168, 403-412. [CrossRef] [PubMed]

15. Lindstedt, B.A.; Finton, M.D.; Porcellato, D.; Brandal, L.T. High frequency of hybrid Escherichia coli strains with combined Intestinal Pathogenic Escherichia coli (IPEC) and Extraintestinal Pathogenic Escherichia coli (ExPEC) virulence factors isolated from human faecal samples. BMC Infect. Dis. 2018, 18, 544. [CrossRef] [PubMed]

16. Maloo, A.; Fulke, A.B.; Khade, K.; Sharma, A.; Sukumaran, S. Virulence gene and antibiogram profile as markers of pathogenic Escherichia coli in tropical beaches of North Western India: Implications for water quality and human health. Estuar. Coast. Shelf Sci. 2018, 208, 118-130. [CrossRef] 
17. Beninati, C.; Reich, F.; Muscolino, D.; Giarratana, F.; Panebianco, A.; Klein, G.; Atanassova, V. ESBL-Producing Bacteria and MRSA Isolated from Poultry and Turkey Products Imported from Italy. Czech J. Food Sci. 2015, 33, 2015-2097. [CrossRef]

18. Marotta, S.M.; Giarratana, F.; Calvagna, A.; Ziino, G.; Giuffrida, A.; Panebianco, A. Study on microbial communities in domestic kitchen sponges: Evidence of Cronobacter sakazakii and Extended Spectrum Beta Lactamase (ESBL) producing bacteria. Ital. J. Food Saf. 2019, 7, 7672. [CrossRef] [PubMed]

19. Marshall, B.M.; Levy, S.B. Food animals and antimicrobials: Impacts on human health. Clin. Microbiol. Rev. 2011, 24, 718-733. [CrossRef]

20. Overdevest, I.; Willemsen, I.; Rijnsburger, M.; Eustace, A.; Xu, L.; Hawkey, P.; Heck, M.; Savelkoul, P.; Vandenbroucke-Grauls, C.; van der Zwaluw, K.; et al. Extended-spectrum beta-lactamase genes of Escherichia coli in chicken meat and humans, The Netherlands. Emerg. Infect. Dis. 2011, 17, 1216-1222. [CrossRef] [PubMed]

21. van den Bogaard, A.E.; Stobberingh, E.E. Epidemiology of resistance to antibiotics. Links between animals and humans. Int. J. Antimicrob. Agents 2000, 14, 327-335. [CrossRef]

22. Arias, C.A.; Murray, B.E. Antibiotic-resistant bugs in the 21st century-A clinical super-challenge. N. Engl. J. Med. 2009, 360, 439-443. [CrossRef]

23. Pitout, J.D.D.; Laupland, K.B. Extended-spectrum $\beta$-lactamase-producing Enterobacteriaceae: An emerging public-health concern. Lancet Infect. Dis. 2008, 8, 159-166. [CrossRef]

24. Chong, Y.; Ito, Y.; Kamimura, T. Genetic evolution and clinical impact in extended-spectrum beta-lactamase-producing Escherichia coli and Klebsiella pneumoniae. Infect. Genet. Evol. 2011, 11, 1499-1504. [CrossRef]

25. Sanjit Singh, A.; Lekshmi, M.; Prakasan, S.; Nayak, B.B.; Kumar, S. Multiple Antibiotic-Resistant, Extended Spectrum-betaLactamase (ESBL)-Producing Enterobacteria in Fresh Seafood. Microorganisms 2017, 5, 53. [CrossRef] [PubMed]

26. Paterson, D.L.; Bonomo, R.A. Extended-spectrum beta-lactamases: A clinical update. Clin. Microbiol. Rev. 2005, 18, 657-686 [CrossRef] [PubMed]

27. Abdallah, M.; Benoliel, C.; Drider, D.; Dhulster, P.; Chihib, N.E. Biofilm formation and persistence on abiotic surfaces in the context of food and medical environments. Arch. Microbiol. 2014, 196, 453-472. [CrossRef] [PubMed]

28. Colagiorgi, A.; Bruini, I.; Di Ciccio, P.A.; Zanardi, E.; Ghidini, S.; Ianieri, A. Listeria monocytogenes Biofilms in the Wonderland of Food Industry. Pathogens 2017, 6, 41. [CrossRef]

29. Galie, S.; Garcia-Gutierrez, C.; Miguelez, E.M.; Villar, C.J.; Lombo, F. Biofilms in the Food Industry: Health Aspects and Control Methods. Front. Microbiol. 2018, 9, 898. [CrossRef]

30. Mellata, M.; Johnson, J.R.; Curtiss, R., 3rd. Escherichia coli isolates from commercial chicken meat and eggs cause sepsis, meningitis and urinary tract infection in rodent models of human infections. Zoonoses Public Health 2018, 65, 103-113. [CrossRef]

31. Stromberg, Z.R.; Johnson, J.R.; Fairbrother, J.M.; Kilbourne, J.; Van Goor, A.; Curtiss, R.R.; Mellata, M. Evaluation of Escherichia coli isolates from healthy chickens to determine their potential risk to poultry and human health. PLoS ONE 2017, 12, e0180599. [CrossRef]

32. Rouger, A.; Tresse, O.; Zagorec, M. Bacterial Contaminants of Poultry Meat: Sources, Species, and Dynamics. Microorganisms 2017, 5, 50. [CrossRef]

33. Alloui, N.; Bennoune, O. Poultry production in Algeria: Current situation and future prospects. Worlds Poult. Sci. J. 2013, 69, 613-620. [CrossRef]

34. Baliere, C.; Rince, A.; Delannoy, S.; Fach, P.; Gourmelon, M. Molecular Profiling of Shiga Toxin-Producing Escherichia coli and Enteropathogenic E. coli Strains Isolated from French Coastal Environments. Appl. Environ. Microbiol. 2016, 82, 3913-3927. [CrossRef] [PubMed]

35. Wang, J.; Zhao, G.; Gao, Y.; Xu, H.; Mohamed, L.; Zhao, J.; Gai, W.; Zou, M.; Cui, Z.; Yan, S.; et al. Virulence and Antimicrobial Characteristics of Escherichia coli Isolated from Diseased Chickens in China and Algeria. J. Adv. Agric. 2019, 10, 1821-1833. [CrossRef]

36. Mellata, M.; Bakour, R.; Jacquemin, E.; Mainil, J.G. Genotypic and phenotypic characterization of potential virulence of intestinal avian Escherichia coli strains isolated in Algeria. Avian Dis. 2001, 45, 670-679. [CrossRef] [PubMed]

37. Doane, C.A.; Pangloli, P.; Richards, H.A.; Mount, J.R.; Golden, D.A.; Draughon, F.A. Occurrence of Escherichia coli O157:H7 in diverse farm environments. J. Food Prot. 2007, 70, 6-10. [CrossRef]

38. Ferens, W.A.; Hovde, C.J. Escherichia coli O157:H7: Animal reservoir and sources of human infection. Foodborne Pathog. Dis. 2011, 8, 465-487. [CrossRef]

39. Koochakzadeh, A.; Badouei, M.A.; Salehi, T.Z.; Aghasharif, S.; Soltani, M.; Ehsan, M.R. Prevalence of Shiga Toxin-Producing and Enteropathogenic Escherichia coli in Wild and Pet Birds in Iran. Braz. J. Poult. Sci. 2015, 14, 5. [CrossRef]

40. Persad, A.K.; LeJeune, J.T. Animal Reservoirs of Shiga Toxin-Producing Escherichia coli. Microbiol. Spectr. 2014, 2, EHEC-0027-2014. [CrossRef]

41. Poole, T.; Sheffield, C. Use and misuse of antimicrobial drugs in poultry and livestock: Mechanisms of antimicrobial resistance. Pak. Vet. J. 2013, 33, 266-271.

42. Johnson, T.J.; Logue, C.M.; Johnson, J.R.; Kuskowski, M.A.; Sherwood, J.S.; Barnes, H.J.; DebRoy, C.; Wannemuehler, Y.M.; Obata-Yasuoka, M.; Spanjaard, L.; et al. Associations between multidrug resistance, plasmid content, and virulence potential among extraintestinal pathogenic and commensal Escherichia coli from humans and poultry. Foodborne Pathog. Dis. 2012, 9, 37-46. [CrossRef] 
43. Mellata, M. Human and avian extraintestinal pathogenic Escherichia coli: Infections, zoonotic risks, and antibiotic resistance trends. Foodborne Pathog. Dis. 2013, 10, 916-932. [CrossRef]

44. Castanon, J.I. History of the use of antibiotic as growth promoters in European poultry feeds. Poult. Sci. 2007, 86, $2466-2471$. [CrossRef]

45. Agersø, Y.; Jensen, J.D.; Hasman, H.; Pedersen, K. Spread of extended spectrum cephalosporinase-producing Escherichia coli clones and plasmids from parent animals to broilers and to broiler meat in a production without use of cephalosporins. Foodborne Pathog. Dis. 2014, 11, 740-746. [CrossRef]

46. Bondt, N.; Puister-Jansen, L.F. MARAN 2004: Monitoring of Antimicrobial Resistance and Antibiotic Usage in Animals in the Netherlands in 2004; CIDC-Lelystad, LEI Wageningen UR, VWA, RIVM: Lelystad, The Netherlands, 2005.

47. Boutaiba Benklaouz, M.; Aggad, H.; Benameur, Q. Resistance to multiple first-line antibiotics among Escherichia coli from poultry in Western Algeria. Vet. World 2020, 13, 290-295. [CrossRef]

48. Hussain, A.; Ranjan, A.; Nandanwar, N.; Babbar, A.; Jadhav, S.; Ahmed, N. Genotypic and phenotypic profiles of Escherichia coli isolates belonging to clinical sequence type 131 (ST131), clinical non-ST131, and fecal non-ST131 lineages from India. Antimicrob. Agents Chemother. 2014, 58, 7240-7249. [CrossRef]

49. Nandanwar, N.; Hussain, A.; Ranjan, A.; Jadhav, S.; Ahmed, N. Population structure and molecular epidemiology of human clinical multi-drug resistant (MDR) Escherichia coli strains from Pune, India. Int. J. Infect. Dis. 2016, 45, 343-344. [CrossRef]

50. Shaik, S.; Kumar, N.; Lankapalli, A.K.; Tiwari, S.K.; Baddam, R.; Ahmed, N. Contig-Layout-Authenticator (CLA): A Combinatorial Approach to Ordering and Scaffolding of Bacterial Contigs for Comparative Genomics and Molecular Epidemiology. PLoS ONE 2016, 11, e0155459. [CrossRef] [PubMed]

51. Dierikx, C.M.; van der Goot, J.A.; Smith, H.E.; Kant, A.; Mevius, D.J. Presence of ESBL/ AmpC-producing Escherichia coli in the broiler production pyramid: A descriptive study. PLOS ONE 2013, 8, e79005. [CrossRef]

52. Mo, S.S.; Slettemeås, J.S.; Berg, E.S.; Norström, M.; Sunde, M. Plasmid and Host Strain Characteristics of Escherichia coli Resistant to Extended-Spectrum Cephalosporins in the Norwegian Broiler Production. PLoS ONE 2016, 11, e0154019. [CrossRef] [PubMed]

53. Belmahdi, M.; Bakour, S.; Al Bayssari, C.; Touati, A.; Rolain, J.M. Molecular characterisation of extended-spectrum beta-lactamaseand plasmid AmpC-producing Escherichia coli strains isolated from broilers in Bejaia, Algeria. J. Glob. Antimicrob. Resist. 2016, 6, 108-112. [CrossRef] [PubMed]

54. Benameur, Q.; Tali-Maamar, H.; Assaous, F.; Guettou, B.; Rahal, K.; Ben-Mahdi, M.H. Detection of multidrug resistant Escherichia coli in the ovaries of healthy broiler breeders with emphasis on extended-spectrum beta-lactamases producers. Comp. Immunol. Microbiol. Infect. Dis. 2019, 64, 163-167. [CrossRef]

55. Meguenni, N.; Le Devendec, L.; Jouy, E.; Le Corvec, M.; Bounar-Kechih, S.; Rabah Bakour, D.; Kempf, I. First Description of an Extended-Spectrum Cephalosporin- and Fluoroquinolone- Resistant Avian Pathogenic Escherichia coli Clone in Algeria. Avian Dis. 2015, 59, 20-23. [CrossRef]

56. Tekiner, I.H.; Ozpinar, H. Occurrence and characteristics of extended spectrum beta-lactamases-producing Enterobacteriaceae from foods of animal origin. Braz. J. Microbiol. 2016, 47, 444-451. [CrossRef]

57. Sah, R.S.P.; Dhungel, B.; Yadav, B.K.; Adhikari, N.; Thapa Shrestha, U.; Lekhak, B.; Banjara, M.R.; Adhikari, B.; Ghimire, P.; Rijal, K.R. Detection of TEM and CTX-M Genes in Escherichia coli Isolated from Clinical Specimens at Tertiary Care Heart Hospital, Kathmandu, Nepal. Diseases 2021, 9, 15. [CrossRef]

58. Lee, S.-Y.; Park, Y.-J.; Yu, J.K.; Jung, S.; Kim, Y.; Jeong, S.H.; Arakawa, Y. Prevalence of acquired fosfomycin resistance among extended-spectrum $\beta$-lactamase-producing Escherichia coli and Klebsiella pneumoniae clinical isolates in Korea and IS26-composite transposon surrounding fosA3. J. Antimicrob. Chemother. 2012, 67, 2843-2847. [CrossRef] [PubMed]

59. Bradford, P.A. Extended-spectrum beta-lactamases in the 21st century: Characterization, epidemiology, and detection of this important resistance threat. Clin. Microbiol. Rev. 2001, 14, 933-951. [CrossRef]

60. Habeeb, M.A.; Haque, A.; Iversen, A.; Giske, C.G. Occurrence of virulence genes, $16 \mathrm{~S}$ rRNA methylases, and plasmid-mediated quinolone resistance genes in CTX-M-producing Escherichia coli from Pakistan. Eur. J. Clin. Microbiol. Infect. Dis. 2014, 33, 399-409. [CrossRef]

61. Projahn, M.; Daehre, K.; Semmler, T.; Guenther, S.; Roesler, U.; Friese, A. Environmental adaptation and vertical dissemination of ESBL-/pAmpC-producing Escherichia coli in an integrated broiler production chain in the absence of an antibiotic treatment. Microb. Biotechnol. 2018, 11, 1017-1026. [CrossRef] [PubMed]

62. Wang, R. Biofilms and Meat Safety: A Mini-Review. J. Food Prot. 2019, 82, 120-127. [CrossRef] [PubMed]

63. Flemming, H.C.; Wingender, J. The biofilm matrix. Nat. Reviews. Microbiol. 2010, 8, 623-633. [CrossRef]

64. Hall-Stoodley, L.; Costerton, J.W.; Stoodley, P. Bacterial biofilms: From the natural environment to infectious diseases. Nat. Reviews. Microbiol. 2004, 2, 95-108. [CrossRef]

65. Gallant, C.V.; Daniels, C.; Leung, J.M.; Ghosh, A.S.; Young, K.D.; Kotra, L.P.; Burrows, L.L. Common beta-lactamases inhibit bacterial biofilm formation. Mol. Microbiol. 2005, 58, 1012-1024. [CrossRef]

66. Sarantuya, J.; Nishi, J.; Wakimoto, N.; Erdene, S.; Nataro, J.P.; Sheikh, J.; Iwashita, M.; Manago, K.; Tokuda, K.; Yoshinaga, M.; et al. Typical enteroaggregative Escherichia coli is the most prevalent pathotype among E. coli strains causing diarrhea in Mongolian children. J. Clin. Microbiol. 2004, 42, 133-139. [CrossRef]

67. Sheikh, J.; Hicks, S.; Dall'Agnol, M.; Phillips, A.D.; Nataro, J.P. Roles for Fis and YafK in biofilm formation by enteroaggregative Escherichia coli. Mol. Microbiol. 2001, 41, 983-997. [CrossRef] [PubMed] 
68. Tabashsum, Z.; Nazneen, M.; Ahsan, C.R.; Bari, M.L.; Yasmin, M. Influence of Detection Methods in Characterizing Escherichia coli O157:H7 in Raw Goat Meat Using Conventional and Molecular Methods. Biocontrol Sci. 2016, 21, 261-264. [CrossRef]

69. Clinical and Laboratory Standards Institute (CLSI). Performance Standards for Antimicrobial Disk Susceptibility Tests, 27th ed.; Approved Standard; CLSI standard: Wayne, PA, USA, 2017.

70. Arlet, G.; Rouveau, M.; Philippon, A. Substitution of alanine for aspartate at position 179 in the SHV-6 extended-spectrum beta-lactamase. FEMS Microbiol. Lett. 1997, 152, 163-167. [CrossRef]

71. Mabilat, C.; Goussard, S. PCR detection and identification of genes for extended-spectrum beta-lactamases. In Diagnostic Molecular Microbiology: Principles and Applications. American Society for Microbiology; Persing, D.H., Smith, T.F., Tenover, T.C., White, T.J., Eds.; American Society for Microbiology: Washington, DC, USA, 1993; pp. 553-559.

72. Cramton, S.E.; Gerke, C.; Schnell, N.F.; Nichols, W.W.; Götz, F. The intercellular adhesion (ica) locus is present in Staphylococcus aureus and is required for biofilm formation. Infect. Immun. 1999, 67, 5427-5433. [CrossRef] [PubMed]

73. Niu, C.; Gilbert, E.S. Colorimetric method for identifying plant essential oil components that affect biofilm formation and structure. Appl. Environ. Microbiol. 2004, 70, 6951-6956. [CrossRef]

74. Naves, P.; del Prado, G.; Huelves, L.; Gracia, M.; Ruiz, V.; Blanco, J.; Rodriguez-Cerrato, V.; Ponte, M.C.; Soriano, F. Measurement of biofilm formation by clinical isolates of Escherichia coli is method-dependent. J. Appl. Microbiol. 2008, 105, 585-590. [CrossRef] [PubMed] 